\title{
(Web)celebridade: \\ O sujeito ordinário e a narrativa cotidiana sob holofotes
}

\author{
Amanda Meschiatti Vasconcellos ${ }^{1}$ \\ Daniela Zanetti ${ }^{2}$
}

\begin{abstract}
Resumo:Este artigo tem por objetivo localizar a celebridade como um elemento simbólico ativo na vida cotidiana e compreender sua ascensão enquanto espírito de nosso tempo. Para isso, é necessário adentrar ao fenômeno das webcelebridades, isto é, as celebridades que se originam da internet, rompendo com o estatuto histórico da fama e transformando o cotidiano de seus personagens (o homem ordinário) em assuntos passíveis de serem espetacularizados.
\end{abstract}

Palavras-chave: celebridade; sujeito ordinário; cotidiano; capitalismo afetivo; cibercultura.

\begin{abstract}
This paper aims to place the celebrity as an active symbolic element in everyday life and explain it ascent as the spirit of our time, zeitgeist. For this, it isnecessary get into the webcelebrity phenomenon, in other words, celebrities that are made from the internet, breaking off the historical status of fame and transforming the daily life of its characters (the ordinary man) in a content that can be convert in entertainment.
\end{abstract}

Keywords: celebrity; ordinary subject; everyday life; emotional capitalism; cyberculture.

A discussão acerca da relação webcelebridade e cotidianidade, conforme propomos aqui, parte de três perspectivas que foram colocadas no texto no intuito de criar um caminho teórico que possibilitasse a melhor compreensão do fenômeno e do deslocamento que ele promove, isto é, a ruptura que retira o monopólio da fama das mãos de uma elite nobre e artística e a democratiza, por meio das novas técnicas de comunicação operadas pela web, possibilitando a celebridade do homem comum em sua ordinariedade habitual. Assim, tratamos de iniciar a argumentação com uma perspectiva que conecta a vida cotidiana, seu esvaziamento e ressignificação, e a

\footnotetext{
${ }^{1}$ Mestranda de Comunicação e Territorialidades pela Universidade Federal do Espírito Santo (UFES), graduada em Comunicação Social (UFES). E-mail: amandameschivas@gmail.com.

${ }^{2}$ Professora do Departamento de Comunicação Social da Universidade Federal do Espírito Santo (UFES). Doutora em Comunicação e Cultura Contemporâneas pela Universidade Federal da Bahia (UFBA). E-mail: daniela.zanetti@gmail.com.
} 
ascensão das celebridades, como figuras de apoio e padronização do eu, a serviço do status quo que passam a colonizar esta ambiência. Em um segundo momento, comentamos acerca da elevação do sujeito ordinário e de suas narrativas do banal ao posto de serem passíveis de midiatização. Na terceira etapa, esmiuçamos o fenômeno da webcelebridade, figura que nasce do próprio cotidiano, transformando-o em entretenimento e, portanto, tornando este cotidiano o próprio objeto à venda.

\section{As colonizações do cotidiano}

Até o final dos anos 1940 e nos anos 1950, o cotidiano "era a constelação vaga de espaços e tempos fora de tudo que era organizado e institucionalizado em torno do trabalho, da conformidade social e do consumismo" (CRARY, 2014, p. 40), um espaço onde o indivíduo permanecia anônimo e, portanto, podia suspender sua fachada 3 .

A partir daí, conforme remonta Crary (2014), recapitulando as visões de Lefbreve e Debord, observou-se uma ocupação cada vez mais expansiva da vida cotidiana pelo consumo, pelo lazer organizado e pelo espetáculo. Em Comentários sobre a sociedade do espetáculo, publicado originalmente em 1967, Debord falava consoante à leitura de Crary (2014) - sobre um esvaziamento de toda a substancialidade da vida cotidiana de acordo com os interesses das indústrias.

Essa ideia norteia a exposição do professor Jonathan Crary em seu livro 24/7capitalismo tardio e fins do sono. Segundo o autor, o sono seria a única barreira que a vida cotidiana ainda impõe ao capitalismo, uma resistência genuína que ao contrário da fome, da sede, do desejo sexual, da necessidade de afeto e de outras necessidades "irredutíveis" da vida humana, não pode ser eliminada ou monetizada, funcionando como um empecilho para a roda econômica.

Giddens (2002) fala de instituições modernas que interferem nos hábitos e costumes tradicionais. Para ele, "a modernidade altera radicalmente a natureza da

\footnotetext{
3 Erving Goffman (2011) define por fachada o "equipamento expressivo de tipo padronizado intencional ou inconscientemente empregado pelo indivíduo durante sua representação" (ibid., p. 29), isto é, a própria imagem valorizante que tentamos passar para os outros nos processos comunicativos.
} 
vida social cotidiana e afeta os aspectos mais pessoais de nossa existência” (ibid., p. 9).

No processo de colonização das esferas cotidianas, podemos observar o tempo, o amor e a morte, por exemplo, tornarem-se pautas de entretenimento, sendo esvaziadas, ressignificadas e mercantilizadas. De acordo com Illouz (2011), Adorno sugeria, há mais de meio século, também a mercantilização da individualidade:

[...] o credo psicológico, a literatura de autoajuda, a indústria do aconselhamento, o Estado, a indústria farmacêutica e a tecnologia da internet, todos se entremeiam para formar o substrato da personalidade psicológica moderna, pois todos têm no eu o seu alvo primário. Foi a essa fusão progressiva dos repertórios do mercado com as linguagens do eu, durante o século XX, que dei o nome de "capitalismo afetivo" (ILLOUZ, 2011, p. 68).

Berger e Luckmann (1991) citam a linguagem como um princípio organizador da vida cotidiana. A linguagem constrói símbolos que podem ser tomados por objetivamente reais e, portanto, pode também ser usada como ferramenta no processo de colonização do eu.

[...] A linguagem constrói, então, imensos edifícios de representação simbólica que parecem elevar-se sobre a realidade da vida cotidiana como gigantescas presenças de outro mundo. A religião, a filosofia, a arte e a ciência são os sistemas de símbolos historicamente mais importantes deste gênero. A simples menção destes temas já representa dizer que, apesar do máximo desprendimento da experiência cotidiana que a construção desses sistemas requer, podem ter na verdade grande importância para a realidade da vida cotidiana. A linguagem é capaz não somente de construir símbolos altamente abstraídos da experiência diária, mas também de "fazer retornar" estes símbolos, apresentando-os como elementos objetivamente reais na vida cotidiana. Desta maneira, o simbolismo e a linguagem simbólica tornam-se componentes essenciais da realidade da vida cotidiana e da apreensão pelo senso comum desta realidade. Vivo em um mundo de sinais e símbolos todos os dias (BERGER, LUCKMANN; 1991, p. 6o-61, grifo dos autores).

As celebridades, um dos grandes mitos do capitalismo, invadem a vida comum por meio da linguagem. Agindo como um símbolo da "ideologia dominante do capitalismo" (MARSHALL, 1992, p. 9), a celebridade funciona como um operáriomercadoria a executar o que nenhuma máquina burguesa conseguira fazer até então: colonizar mentes e corações. 
Rojek (2008) comenta que para a maioria da classe média americana dos anos 1950, as estrelas do cinema recebiam uma fortuna pelo que faziam e demonstravam gostar de seu trabalho, outro fato que constituía um espanto para os grupos trabalhadores. Assim, o significado embutido no signo-celebridade servia como uma promessa, uma esperança de sucesso, do dinheiro "fácil", de diferenciação, da possibilidade de escolhas, da liberdade e da flexibilidade do estilo de vida (ROJEK, 2008, p. 192). Em resumo, "o sistema de heróis modernos reforça o status quo" (MARSHALL, 1992, p. 31-32, tradução nossa).

Como é da ordem do mito, no sentido proposto por Barthes (2001), a celebridade também se purifica das marcas da produção humana e de seus interesses intrínsecos, tornando-se naturalizada. Em outras palavras, "o significado dado tornase o real" (MARSHALL, 1992). Isto é, tudo o que a celebridade representa enquanto signo é consumido como verdadeiro em um processo irrefletido. Para Benetti e Hagen (2008), a ocultação dessa complexidade é apenas uma das características da vida cotidiana.

Por meio das celebridades e de outros espetáculos humanos da ficção, o indivíduo moderno consegue emular comportamentos como fonte de seu próprio eu. Rojek (2008) atribui aos apegos psíquicos envolvidos nesse processo o protagonismo na formação identitária. Bem como os religiosos, os fãs buscam na figura da celebridade uma âncora de sustentação para certas instâncias de sua vida pessoal (ROJEK, 2008).

Para a professora Beatriz Bretas, a "ambiência cotidiana abriga as expressões das pessoas comuns e os discursos midiáticos em constante processo de intercâmbio de argumentos" (BRETAS, 2006, p. 35). Hoje, a celebridade - como um superhumano criado pelo capitalismo - participa desses discursos midiáticos e, portanto, tem seu lugar firmado no cotidiano, sendo um ator (artificial) que se inseriu nessa realidade.

Os modos comuns de dizer e fazer, vistos como práticas cotidianas, são formas que possibilitam processos identitários ao apresentarem regularidades e padrões compartilhados socialmente, permitindo que uns se reconheçam nos outros. [...] A aferição e a análise da experiência vivida, destacando a produção e o consumo de materiais simbólicos pelos autores envolvidos, prestam-se a identificar valores e significados próprios de comunidades ou redes de pertencimento (BRETAS, 2006, p. 32). 
Giddens (2002) atribui a ascensão desse tipo de instituição (a celebridade) ao rompimento da modernidade com o referencial protetor da comunidade e da tradição, que são substituídas por organizações maiores e impessoais. $\mathrm{O}$ autor inglês exemplifica que "a terapia oferece alguém para quem podemos nos voltar, uma versão secular do confessionário" (GIDDENS, 2002, p. 38) e nós completamos que a celebridade fornece um referencial de identidade, que agora pode ser criada e recriada de acordo com a disponibilidade dos modelos oferecidos.

Richard Dyer (2005, p. 15 apud JORGE, 2014, p. 44) aponta que "estrelas representam formas típicas de comportamento, sentimento e pensamento na sociedade contemporânea" influenciando valores culturais da vida prática, tais como a relação que estabelecemos com "trabalho, sexualidade, etnicidade e identidade sexual".

A noção de estilo de vida, quase sempre emulada de alguma celebridade ou personagem midiática, faz parte de um projeto reflexivo do eu em manter narrativas biográficas coerentes e emerge como um elemento importante na estruturação da "autoidentidade e da atividade diária" (GIDDENS, 2002, p. 12-13), sendo, portanto, também estruturante da própria sociedade.

A celebridade, por conseguinte, já é figura que se encontra no cerne das relações sociais, parassociais e subjetivas dos tempos hodiernos, sendo um componente do cotidiano espetacular de nossas sociedades varridas pela cultura de massa.

\section{O protagonismo do sujeito ordinário}

Somado a isso, o status da fama adquire cada vez mais força em nossas mentalidades, sendo uma nova pauta na vida do homem comum. Alex Primo (2009), em sua investigação precursora no Brasil sobre a busca de fama na web, aponta dados de pesquisa do PewResearch Center 4 realizada em 2006. O interesse do estudo era identificar, entrevistando jovens entre 18 e 25 anos, os principais objetivos dessa

4Pesquisa publicada originalmente no site oficial do Pew Research Center. Disponível em: <http://www.people-press.org/2007/01/o9/a-portrait-of-generation-next/>. Acesso em: 9 nov. 2016. 
geração. Assim, "ser famoso" foi a escolha de $51 \%$ dos respondentes, perdendo apenas para a opção "ficar rico", que alcançou $81 \%$ das respostas. Na Inglaterra, pesquisa 5 semelhante foi realizada no mesmo ano com crianças de até 10 anos. A pergunta em questão era qual seria a "melhor coisa do mundo" e, desta vez, "ser uma celebridade" foi a alternativa mais popular.

A celebridade infiltrou-se nas subjetividades e a fama se tornou o espírito de nosso tempo, à medida que se traduz em um anseio coletivo que se cristaliza por meio das novas (e mais acessíveis) tecnologias massivas de comunicação.

Com o advento (e barateamento) de tecnologias de projeção de si, o consumidor médio passou a ter acesso às técnicas de midiatização do self, e uma nova onda de conteúdos referentes ao banal e ao cotidiano voltou a ganhar notoriedade no final do século XX. O espectador não estava condenado a essa posição. Podia agora ser protagonista de sua própria vida-filme, podia ser um espetáculo de si mesmo (SIBILIA, 2008). Ou tornar-se "entretenimento humano", o que na leitura de NealGabler (1999, p. 157) seria sinônimo de celebridade.

O pedestal artístico e inalcançável da celebridade hoje é habitado por qualquer um que se sobressaia da massa de desconhecidos (GABLER, 1999), desde políticos, empresários, jornalistas e top models a criminosos, cabeleireiros, moças que posam para revistas de nudez, blogueiros, pessoas que se tornam memes ${ }^{6}$ da internet, ou que simplesmente criam perfis que reúnem múltiplos seguidores e, por fim (mas nessa mesma categoria), youtubers.

O que se observa, portanto, é a potencialização das possibilidades de se tornar celebridade (FRANÇA, 2014), refletindo em uma democratização sem precedentes do poder discursivo na sociedade (ROJEK, 2008). Nesse mesmo sentido, França (2014) salienta o esfacelamento do monopólio da fama de uma elite de nobres para uma elite burocrática, e logo depois para uma casta artística manipulada pelo capital até,

5Para mais detalhes sobre essa pesquisa, há uma matéria publicada no site do Daily Mail. Disponível em: <http://www.dailymail.co.uk/news/article-423273/Being-celebrity-bestthing-world-say-children.html >. Acesso em: 9 nov. 2016.

${ }^{6}$ Conteúdo imagético ou audiovisual de caráter cômico criado ou publicado na internet e nela espraiado com força viral. 
finalmente, chegar ao apogeu da ascendência do homem comum em sua ordinariedade.

Edgar Morin (1989, p. 21, grifo do autor), em analogia que liga a celebridade aos deuses7, afirma que "Ser reconhecido como homem é, antes de mais nada, ver reconhecido o direito de imitar os deuses". Se antes apenas os reis e figuras detentoras de representatividade política o conseguiam, o fluxo histórico da fama concede, agora, também aos plebeus esse direito.

Ao discorrer acerca do eu espetacularizado contemporâneo, Sibilia (2008) resgata a pesquisa de David Riesman, que sublinha a transição na forma de autoconstrução do norte-americano no início do século XX, partindo de uma personalidade introdirigida para outra alterdirigida, o que pressupõe a existência de um público que a acompanhe, assim como o espectador, o espetáculo.

Na pretensão de ser amado, apreciado e aplaudido, os indivíduos estariam submetidos ao que Paula Sibilia (2008, p. 90) nomeou "tiranias da visibilidade",tendo que estilizar e cultivar suas imagens aos moldes de personagens da mídia audiovisual e "atuar como se estivesse sempre diante de uma câmera, disposto a se exibir em qualquer tela". Gabler (1999, p. 16) fala em "interpretar" a própria vida com base em habilidades sociais, ao invés de simplesmente vivê-la. O Homo sapiens estaria se tornando, na ótica do autor, um "Homo scaenicus", isto é, um artista por natureza.

Vivemos tempos em que as personalidades são convocadas e a visibilidade se constitui em uma nova forma de existir nas sociedades ocidentais (SIBILIA, 2008). Christoph Türcke (2010) resgata e atualiza uma esquecida proposição dos anais filosóficos para tratar das sensações que incidem sobre o sujeito contemporâneo: esse est percipi, o que se traduz em "ser é ser percebido". Nas palavras do filósofo: "quem não emite não é, ou seja, ele pode estar tão vivo quanto possível, ter os melhores parâmetros sanguíneos e o melhor caráter; midiaticamente está morto" (TÜRCKE, 2010, p. 46) e esta ilusão midiática que define alguém como "morto" é a ordem da

7Edgar Morin (1989; 2007) trabalha a hipótese de que as celebridades seriam os olimpianos da modernidade. Isto é, as vedetes do espetáculo midiático teriam se elevado ao patamar dos antigos deuses da mitologia grega ao passarem a ser idolatradas e servirem de modelo à humanidade. 
vez, pois é ela que delimita quem é "alguém" - isto é, ser reverenciado e levado em consideração - e quem não é.

A socióloga dos afetos Eva Illouz (2011) demarca esse intenso interesse no eu comum e na "normalidade" como tendo início nas propostas de Freud, que se popularizaram midiaticamente a partir dos anos 1950. A autora comenta acerca de um "estilo afetivo terapêutico" que passou a dominar as agendas. Esse momento traduz a repentina preocupação da cultura do século XX com aquilo que se referia aos afetos, aos comportamentos e a repensar a esfera íntima.

Freud problematizou a noção de normalidade, transformando-a em uma meta a ser alcançada, não um dado. Em outras palavras, essa filosofia permitia ao sujeito a possibilidade em aberto da construção de eus diversos, o que desperta um maior interesse em se conhecer o indivíduo ordinário em suas peculiaridades, que podiam tanto tender à normatividade quanto à patologia. A personalidade do homem ordinário se firmava como um mistério a ser solucionado.

O "humantouch" ou "humaninterest" 8 jornalístico é uma outra parte do processo que elevou o homem comum à categoria de midiatizável. A informação passa a ser romanceada e vedetizada aos moldes dos filmes e novelas, e traz do anonimato os personagens mais comoventes e apelativos de situações corriqueiras como casamentos, divórcios, partos e acidentes (MORIN, 2007) por meio do processo de projeção-identificação também observado entre as audiências e os ídolos do cinema. Morin (2007, p. 100-101) recorda as grandes catástrofes que são exploradas pelos noticiários como épicos do cinema recheados de estratégias emocionais: "[...] as crianças mártires apelam para a afetividade materna, os crimes passionais apelam para a afetividade amorosa, os acidentes apelam para o pathos elementar".

Um exemplo nacional encontra-se no caso de Geisy Arruda, uma celebridade que se firmou como persona televisiva após ser hostilizada por cerca de 700 colegas na universidade em que estudava em São Paulo, em 2009, por conta de seu vestuário ter sido considerado vulgar (FREIRE FILHO; LANA, 2014). Vídeos da agressão, gravados pelos próprios alunos, ganharam as manchetes de todas as mídias do país.

\footnotetext{
${ }^{8}$ Em tradução livre, "toque humano" e "interesse pelo humano”, respectivamente.
} 
O caso repercutiu de maneira tão prolongada que possibilitou que Geisy alçasse projeção midiática para outros projetos que envolviam sua fama enquanto celetóide.

A ideia de celebrizar-se ganha sequência nos dias atuais com as narrativas autobiográficas que se fixam em espaços da Internet:

Independente da quantidade de leitores ou espectadores que de fato consigam recrutar, os adeptos dos novos recursos da Web 2.0 costumam pensar que seu presunçoso eu tem o direito de possuir uma audiência, e a ela se dirigem como autores, narradores e protagonistas de tantos relatos, fotos e vídeos com tom intimista (SIBILIA, 2008, p. 74).

Para Sibilia (2008, p. 33), estes novos métodos de "criação de si” vão muito além do registro histórico, do testemunhar, mas exalam um poder mágico que concede "realidade" à própria existência. Na percepção da autora, os relatos autobiográficos que se amparam em dispositivos imagéticos não apenas tecem a vida do eu, mas a realizam.

Os gêneros autobiográficos, que agora pululam na internet, exigem do autor mais do que a narração de uma história, mas também que seja o protagonista da história contada (SIBILIA, 2008, p. 150). Sendo assim, o embrião humano responsável pela união entre o enunciador e seu público atinge seu suprassumo.

Sibilia (2008, p. 203) acentua a ancoragem que relatos autobiográficos do ciberespaço têm no absolutamente banal, comum e rasteiro de cada vida e em sua capacidade para se tornarem espetáculos. Em concordância com Guy Debord, esses fragmentos da vida, quando expostos em rede, acabam por constituir "uma relação social entre pessoas mediadas por imagens".

\section{As webcelebridades e o cotidiano midiatizado}

Graeme Turner, atento às modificações no estatuto da celebridade, define a celebridade DIY (do inglês do it yourself: "faça você mesmo"), uma nova categoria de persona pública que "cria seu próprio site, gera seu próprio conteúdo e publica suas próprias performances de si” (2004, p. 65, tradução nossa), em um processo autogerado possibilitado pela Web 2.o. No entanto, para o professor, a integração dessa nova celebridade nos grandes setores da mídia é mínima se comparada às celebridades oriundas da televisão ou da música, por exemplo. 
Jorge (2014) revela que a ideia da celebridade $D I Y$ ganha força na internet e atrai os jovens para a ideia de que podem ser famosos por si próprios, exemplo do astro da música Justin Bieber que, após ser visto por milhões de pessoas em seu canal no YouTube em 2009, conseguiu editar um álbum e adentrou ao panteão das grandes celebridades internacionais, onde se mantém até hoje, integrando-se totalmente à grande mídia, o que refuta em parte o conceito de DIY conforme Turner (2004).

A webcelebridade parte do conceito DIY celebrity, mas não se resume a ele. Esse novo ator da cibercultura nasce das relações estabelecidas pelo contexto digital; é cidadão desse território; sua produção está estabelecida nele; interage com usuários que são bits - estes também descorporizados e mediados pela linguagem eletrônica ; ganha visibilidade multitudinária em uma mídia massiva através de relatos que, mesmo podendo perpassar referenciais distintos, acabam se construindo em cima da imagem unificada do usuário autor do discurso, que se torna famoso nas redes.

Neste sentido, um exemplo é o blogueiro Hugo Gloss9. Ainda que o mote de suas postagens nas redes sociais e em seu site sejam fofocas sobre a vida dos famosos e o resumo de telenovelas, sua figura é onisciente (sua marca é ele mesmo: Hugo Gloss) e seu modo de fala perpassa todas as narrativas, funcionando como um atrativo cômico para seus seguidores

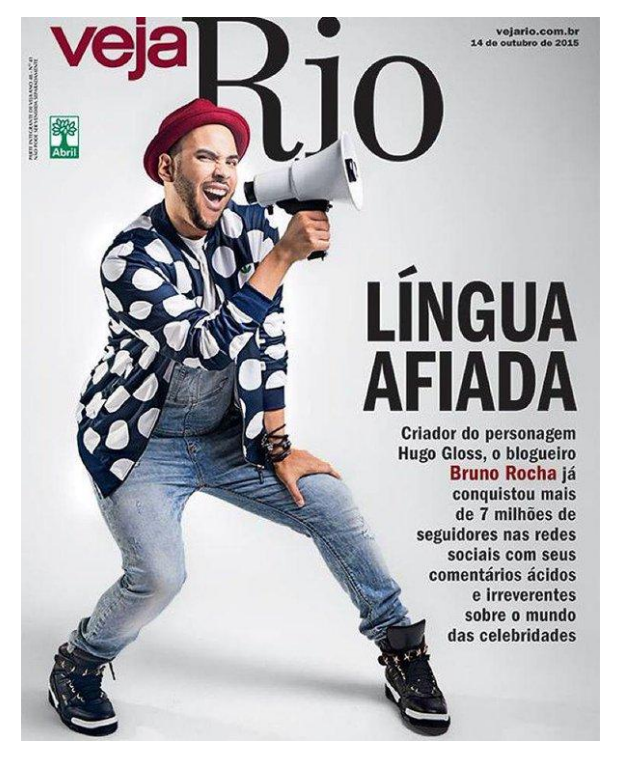

9Hugo Gloss na verdade é Bruno Rocha. Sua carreia começou com uma conta no Twitter, onde fazia comentários ácidos que beiravam ao cômico sobre a vida das celebridades, até que ele próprio se tornou uma. Do Twitter, Gloss expandiu sua marca para um blog de mesmo nome e perfis em redes sociais que reúnem milhões de seguidores. 
Figura 1: Blogueiro Hugo Gloss é capa da revista Veja Rio.

Fonte: Twitter

Quando buscamos arquétipos de webcelebridades que se fazem a partir de performances confessas de si, os exemplos se multiplicam. Na Internet brasileira, o exemplo pioneiro é Mari Moon, que permanece em voga congregando milhares de seguidores até hoje. Em seu blog pessoal, a hoje youtuber e apresentadora de televisão é descrita como uma das personalidades mais importantes do Brasil. Na introdução, explica-se que "Mari Moon foi a primeira famosa na web (2003)"10nacional. Dona de uma carreira que envolve também televisão e cinema, Mari Moon adquiriu o título de webcelebridade após se tornar muito popular postando fotos de si mesma na extinta rede social de fotos, Fotolog.

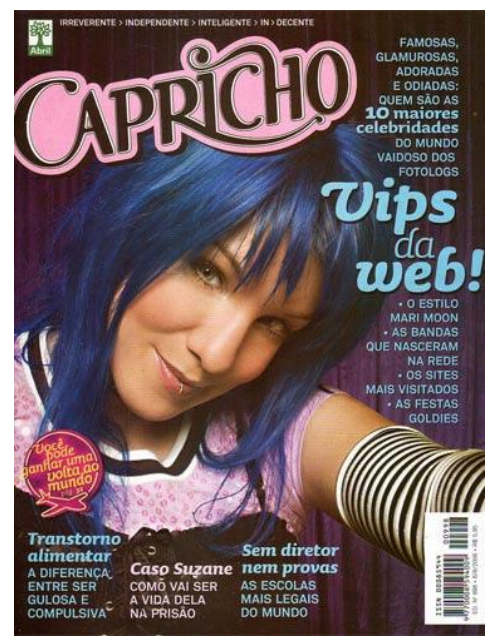

Figura 2: Revista Capricho de agosto de 2006 apresentava Mari Moon como uma celebridade do "vaidoso" mundo dos fotologs.

Fonte: Flickr

A busca de fama nos meios digitais reorganiza as consciências para a constante exibição e acompanhamento de relatos minuciosos da vida. Toda vida torna-se passível de ser midiatizada. A personalidade do autor, suas peripécias, rotinas e opiniões ganham suportes imagéticos, sonoros, textuais, audiovisuais ou todos interligados ao mesmo tempo, na função de mostrar "a vida como ela é" (SIBILIA, 2008, p. 70).

10Informação retirada da seção "Sobre" do próprio blog de Mari Moon. Disponível em: <http://marimoon.com.br/institucional/sobre/>. Acesso em: 7 out. 2016. 
De acordo com Agnes Heller (2008, p. 63 apud BENETTI; HAGEN, 2008, p. 5), a imitação, a ultrageneralização, o pragmatismo e a unidade imediata entre pensamento e ação são marcas do cotidiano, bem como a espontaneidade. A pesquisadora brasileira Angie Biondi (2002), no entanto, demonstra alguma resistência em acreditar na pureza do cotidiano midiatizado. Ao analisar as fotografias de Jeff Wall, por exemplo, a autora problematiza a dicotomia entre a imagem e o "imaginário de um cotidiano", ou seja, aquilo que o produtor do conteúdo visa passar com essa imagem. Nesse contexto, Biondi destaca "aspectos de miseenscène e apropriação de certos recursos narrativos cinematográficos (stills) no que se refere à qualidade visual" (BIONDI, 2010, p. 22) que acabam por construir uma noção de cotidiano, não o demonstrando em sua complexidade.

Essas técnicas de midiatização do cotidiano, como comentado anteriormente, podem ser vistas em todas as redes sociais da internet, se intensificando entre as webcelebridades, que costumeiramente transformam suas rotinas em reality shows que podem ser acompanhados via Instagram, SnapChat ou You Tube, por exemplo. A musa fitness Gabriela Pugliesi, uma influenciadora digital que adquiriu fama na rede social de fotos Instagram, faz de seu dia a dia o assunto principal de seu perfil, que é seguido por quase 3 milhões de usuários.

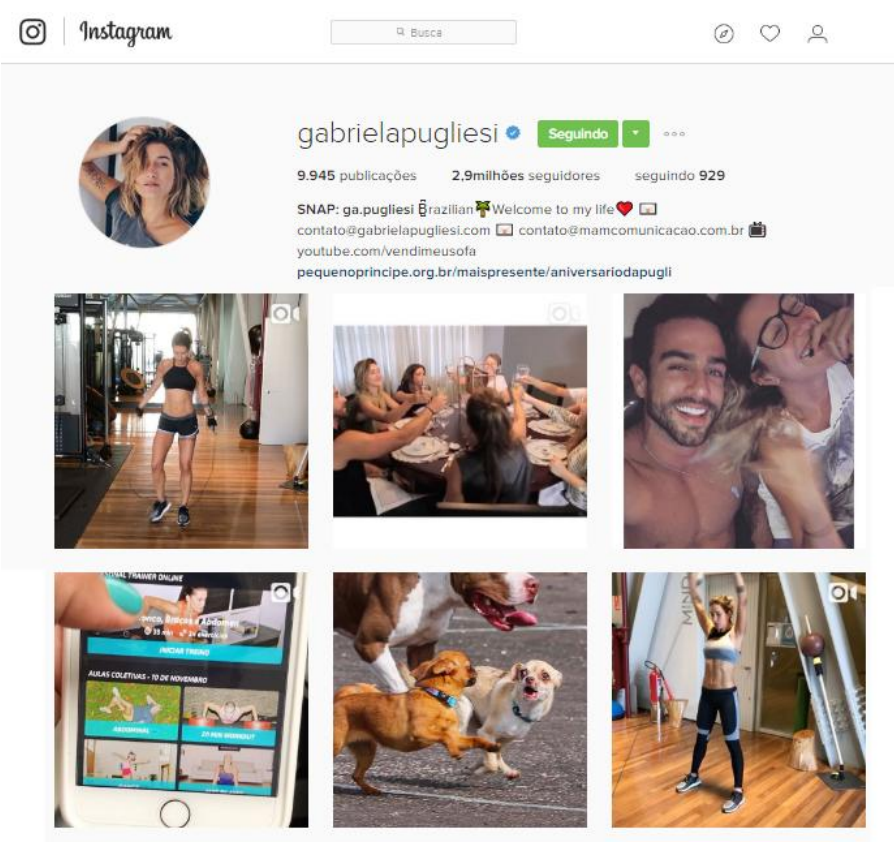

Figura 3: Print screen da conta de Gabriela Pugliesi no Instagram.

Fonte: Instagram 
No You Tube, o segundo link mais acessado da internet mundial e também no Brasil ${ }^{11}$, muitos são os desenvolvedores de conteúdo que tem se tornado celebridades, ganhando capas de revistas, programas e aparições na TV aberta, protagonizando filmes blockbuster, livros que se tornam best-sellers e comerciais para grandes marcas. Entre os inúmeros exemplos que povoam essa infoterritorialidade, destacamos a webcelebridade Taciele Alcolea, cujo canal no You Tube contabiliza quase três milhões de inscritos e mais de 323 milhões visualizações desde que foi lançado, em setembro de 2009.

O assunto principal dos vlogs de Taciele são sua própria vida, suas opiniões sobre filhos, casamento e sonhos. Em vídeos recentes, destacamos a presença do cotidiano como uma constante de conteúdo: Taciele conta que pintou o cabelo e explica como fez; fala sobre suas tatuagens e seus significados; mostra a primeira noite que passou com seu marido no novo apartamento que compraram em São Paulo; vai às compras buscando artigos de decoração para o novo lar e apresenta um dia com ela, como se o espectador pudesse, de fato, acompanhar o ritmo de seu dia, bem próximo da estrela.
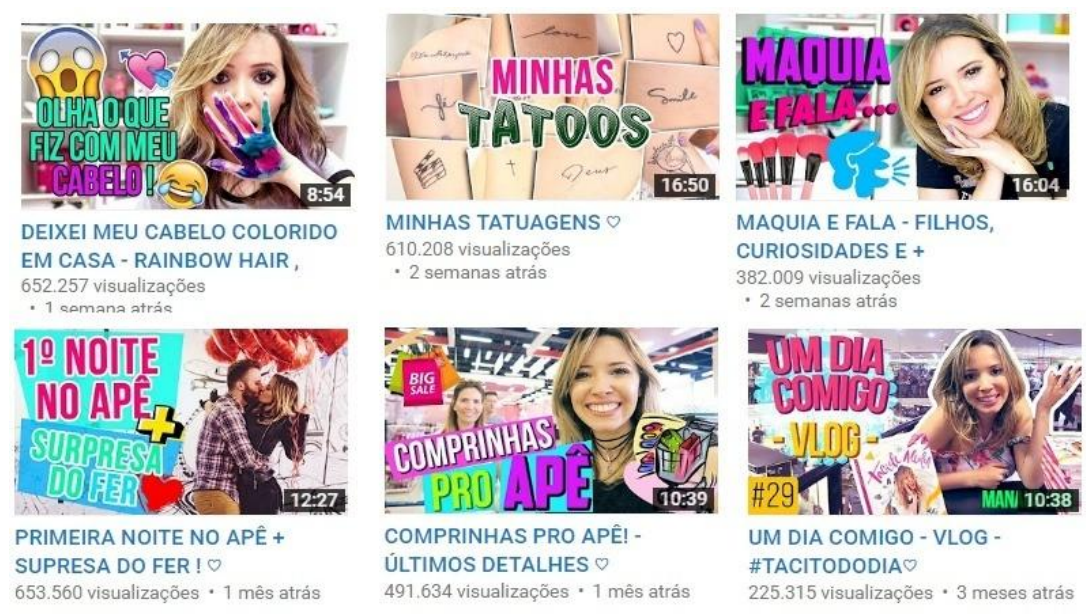

Figura 4: Alguns vídeos recentes do canal de TacieleAlcolea no YouTube. Fonte: YouTube

A relação celebridade, sempre baseada na fidelidade das audiências, em sua atualização para os novos meios digitais pode ser explicada por meio da

${ }^{11}$ Cf. ALEXA. The top 500 sites on the web. 2016. Disponível em: $<$ http://www.alexa.com/topsites >. Acesso em: 15 out. 2016 
sociabilidade. De acordo com Illouz (2011, p. 48), a anulação do corpo pela tecnologia exige a "expressão mais plena do eu autêntico" nas redes, o que arquiteta a sociabilidade por meio de compatibilidades afetivas e exige do cibernauta um esforço maior em mostrar sua identidade ou as marcas que ela permite que sejam visualizadas.

O encontro das múltiplas identidades - a da webcelebridade com a de seus fãs - desencadeia, então, o processo de projeção-identificação, base para que o fenômeno celebridade ocorra e, fundamental, nesse processo que se atualiza na Web.

França (2014, p. 7) afirma que, com a consolidação da Internet, indivíduos comuns têm a chance de tornarem-se notáveis em nichos especializados, "micromundos", que instituem o que convencionou chamar microcelebridades. Uma das apoiadoras deste termo, Adriana Braga (2010) atribuía a escolha do prefixo minimizador ao fato de este fenômeno de celebrização se restringir às redes sociais.

No entanto, acompanhando a expansão multimidiática das celebridades de Internet nos últimos anos, há de se repensar o título para que não seja gerador de confusões de entendimento. A exemplo dos youtubers, podemos afirmar que os famosos do ciberespaço têm ampliado seu alcance para outras formas de mídia, se tornando celebridades em seu sentido amplo, extrapolando as redes sociais e os micromundos de grupos segmentados de espectadores. Por isso, um título mais neutro para esses famosos das redes cibernéticas seria o de webcelebridade.

A fim de concluirmos, podemos assumir que as celebridades (em todas as suas formas) são uma instituição da modernidade que invade diversos âmbitos de nossa vida cotidiana, sendo eles os afetos, os comportamentos, a moda etc. Sua força é tão proeminente que absorveu o homem comum de modo total e, agora, vendem até mesmo o cotidiano destecomodificado em entretenimento.

\section{Referências}

BARTHES, Roland. Mitologias. Rio de Janeiro: Bertrand Brasil, 2001. BENETTI, Marcia; HAGEN, Sean. Jornalismo e vida cotidiana: o comer e o cozinhar contemporâneos nas revistas semanais. In: Revista da Associação Nacional dos Programas de Pós-Graduação em Comunicação | E- 
compós, Brasília, v.11, n.2, maio/ago. 2008. Disponível em:

$<$ http://www.compos.org.br/seer/index.php/ecompos/article/viewFile/228/273

$>$. Acesso em: 25 abr. 2017.

BERGER, P. L.; LUCKMANN, Thomas. A construção social da realidade.

Petrópolis: Vozes, 1991.

BIONDI, Angie. Imagens do Cotidiano ou o Real Construído? O jogo do real e do ficcional na narrativa fotográfica de Jeff Wall. In: LOGOS - Comunicação e Audiovisual. Ano 17, $\mathrm{N}^{\circ} \mathrm{O} 1,1^{\circ}$ semestre 2010. Disponível em: $<$ http://www.logos.uerj.br/PDFS/32/02 logos32 biondi imagensdocotidiano. pdf >. Acesso em: 25 abr. 2017.

BRAGA, Adriana. Microcelebridades: entre meios digitais e massivos. In Contracampo, Niterói/ RJ, $\mathrm{n}^{0}$ 21, p. 39-53, ago., 2010. Disponível em: < http://www.contracampo.uff.br/index.php/revista/article/view/55> . Acesso em: 25 abr. 2017.

BRETAS, Beatriz. Interações cotidianas. In.: GUIMARÃES, César; FRANÇA, Vera (Orgs.). Na mídia, na rua: narrativas do cotidiano. Belo Horizonte: Autêntica, 2006.

CRARY, Jonathan. 24/7 - Capitalismo tardio e os fins do sono. São Paulo: Cosac Naify, 2014.

FRANÇA, V. Celebridades: identificação, idealização ou consumo?. In: FRANÇA, V. et al (Orgs). Celebridades no século XXI: transformações no estatuto da fama. Porto Alegre: Sulina, 2014.

FREIRE FILHO, João; LANA, Lígia. Pacto de Visibilidade: Mídia, Celebridades e Humilhação. In: Revista Contracampo, v. 30, n. 2, ed. Agosto/novembro ano 2014. Niterói: Contracampo, 2014. p 4-23. Disponível em: < http://www.contracampo.uff.br/index.php/revista/article/view/682> . Acesso em: 25 abr. 2017.

GABLER, Neal. Vida, o filme: como o entretenimento conquistou a realidade. São Paulo: Companhia das Letras, 1999.

GIDDENS, Anthony. Modernidade e Identidade. Rio de Janeiro: Jorge Zahar Editor, 2002.

GOFFMAN, Erving. A Representação do Eu na Vida Cotidiana. 18 ed. Petrópolis: Editora Vozes, 2011.

ILLOUZ, Eva. O amor nos tempos do capitalismo. Ed. Zahar, 2011.

JORGE, Ana. O que têm os famosos? - a cultura das celebridades e os jovens portugueses. Portugal: TextoEditores, 2014.

MARSHALL, P. David. Celebrity and Power: Celebrity Status as a Representation of Power in Contemporary Culture. Montreal: Biblioteca Nacional do Canadá, 1992.

MORIN, Edgar. As estrelas: mito e sedução no cinema. Rio de Janeiro: José Olympio, 1989. 
. Cultura de Massas no Século XX: Neurose. 9.ed. Rio de Janeiro:

Forense Universitária, 2007. (O espírito do tempo; v. 1).

PRIMO, Alex. A busca por fama na web: reputação e narcisismo na grande mídia, em blogs e no Twitter. In: XXXII Congresso Brasileiro de Ciências da Comunicação, 2009, Curitiba. Anais.

ROJEK, Chris. Celebridade. Rio de Janeiro: Rocco, 2008.

SIBILIA, Paula. O show do eu: a intimidade como espetáculo. Rio de Janeiro: Nova Fronteira, 2008.

TÜRCKE, Christoph. Sociedade excitada: filosofia da sensação; tradutores:

Antonio A. S. Zuin et al. Campinas: Editora da Unicamp, 2010.

TURNER, Graeme. Understanding celebrity. London/ Thousand Oaks/ New Delhi: SAGE Publications, 2004. 